\title{
Women Civil Society Organisations and the Struggle for Social Justice: Interrogating the Experiences of Women of Zimbabwe Arise (WOZA)
}

\author{
Racheal Mafumbate $^{1} \quad$ Tafadzwa Mafumbate $^{2} \quad$ Maxwell C.C. Musingafi $^{3 *}$ \\ 1.University of Eswatini, Department of Educational Foundations and Management, Faculty of Education \\ 2.Zimbabwe Open University, Department of Peace Studies, Faculty of Applied Social Sciences \\ 3.Zimbabwe Open University, Department of Development Studies, Faculty of Applied Social Sciences
}

\begin{abstract}
This paper explores the relationship between women civil society organisations and the government in Zimbabwe using Woman of Zimbabwe Arise (WOZA) in Bulawayo as case study. WOZA, like other civil society organisations in Zimbabwe, has been increasingly using protests and strikes to confront women and human rights abuses by government. They also employ negotiation techniques as in the case of the Tripartite Negotiation Forum which has been in place since 1997. All these techniques, like several other efforts have been ineffective as evidenced by the increasing gaps in social justice and gender disparities in the country. Respondents claimed that they were raped; exposed to inhuman torture like forcing a bottle into their sexual organ; insulted and called names like whores / prostitutes / beaches; and so on. At organisational level WOZA faced challenges like lack of reliable and sustainable source of funding; violence from government sponsored groups (ZRP, youth, women); and hatred by government authorities who saw the civic organisation as a front for Western imperialists. The paper recommends the establishment of a national policy framework that encourages tolerance and acceptance of diversity; cooperation between men and women in confronting their everyday social and political problems; a partnership model by various stakeholders to solve the socio-economic problems bedeviling the country; among other things.
\end{abstract}

Keywords: women, civil society, organisations, social justice, experiences, WOZA

DOI: $10.7176 / \mathrm{DCS} / 9-4-08$

Publication date: April $30^{\text {th }} 2019$

\section{Introduction}

According to Makumbe (1998) the experience of civil society organisations in the African context entails focusing on the people's struggle against despotic rulers, repressive governments and regimes that violate both their individual and collective rights. The major challenge in this scenario is, thus, the failure between civic organisations and government to work together in resolving conflicts in the country. This paper explores the relationship between women civic organisations and the government in Zimbabwe using Woman of Zimbabwe Arise (WOZA) in Bulawayo as case study.

\section{Defining Civil Society Organisation}

According to the World Health Organisation (WHO) (2014), the term civil society organisations (CSOs) refers to non-state, not-for-profit, voluntary organisations formed by people in their social sphere. The term describes a wide range of organisations, networks, associations, groups and movements that are independent from government and that sometimes come together to advance their common interests through collective action. Traditionally, civil society includes all organisations that occupy the 'social space' between the family and the state, excluding political parties and firms (Ibid).

\section{Civil Society in Zimbabwe}

A wide range of arguments have arisen over the relationship between the state and the civil society. In some cases both the state and the civil society have been viewed as having a contesting relationship, while in other cases the two have been viewed as complementary. At some point scholars have questioned the existence of a civil society in African states. Helliker (2012) writes about the 'Manichean dualism' in Zimbabwean society and politics whereby there is 'civil society progression versus state regression' and quotes various scholars glorifying civil society as, 'flexing its muscles' (Zack-Williams, 2001: 217), and about the 'rebirth of civil societies' (Monga, 1996: 10) as well as about the 'growing civil society structures' (Molutsi, 1999: 188). Helliker (2012), thus, concludes that, 'civil society organisations are viewed as representing the general or universal interests while the state pursues its own partial and particularistic interests.'

According to Sachikonye (2007), before 1999 in Zimbabwe, civil society organisations were acting as de facto political parties. They played roles of opposition parties, except that they were not contesting for political power. Thus civil society organisations can fill the gap where political parties are weak to resist integration into 
authoritarian regime, to dispute its legitimacy, to raise the cost of authoritarian rule and create a credible democratic alternative (Ibid).

Civil societies in Zimbabwe are increasingly using protests and strikes to confront human rights abuses by government. They also employ negotiation techniques as in the case of the Tripartite Negotiation Forum which has been in place since 1997. All these techniques, like several other efforts have been ineffective as evidenced by the increasing gaps in social justice. In spite of including political leaders, traditional leaders, students and business representatives, the Tripartite Negotiation Forum has not yielded the desired results.

Moyo (1993) identifies two different but related historical eras that explain the characteristics of civil society organisations in Zimbabwe. One relates to the pre-independence period and the other to political developments in Zimbabwe since independence.

The pre-independence era criminalised politics in the Black community. Without political activity, the prospect of civil society activities is diminished. For Blacks in Rhodesia, political activity became a clandestine affair as they were forced to organise and coordinate their affairs behind closed doors under life-threatening conditions. In fact, during the colonial period, social movements such as trade unions, student groups, community organisations and political parties in the Black community were trampled upon in an attempt to relegate them to permanent political irrelevance.

In the post-independence era, the political landscape under the new government also failed to bring any positive developments in the civil society in Zimbabwe. Instead the ruling party took advantage of an underdeveloped civil society by claiming that ZANU (PF) was the sole legitimate representative of the people (Moyo, 1993). Under the guise of this claim, the party declared itself to be the umbrella organisation of all social movements and went about destroying civil society associations in the name of 'the revolution'. All 'legitimate' organisations were challenged by ZANU (PF) to join the ruling party as a way of proving their revolutionary and patriotic commitment.

Civil society groups, such as trade unions and student movements, which had operated under ground during the days of colonial government and which had hoped to attain legitimacy after independence were left bleeding by the ruling party's tactics. Other social groups which survived sooner or later found themselves forced to toe the ZANU (PF) party line. This is one of the reasons why, up to now there is no representation for workers and peasants in the ZANU (PF) central committee and politburo - despite the fact that these groups make up the majority in the country.

This paper focuses on women civil society organisations, a segment of civil society organisations. In Zimbabwe women civil organisations came into limelight in the post-independence era. Some of these organisations include the following:

- Women's Coalition of Zimbabwe (WCoZ), a network of women rights activists and women's organisations with national structures. The $\mathrm{WCoZ}$ is a forum where women meet to engage in collective activism on issues affecting women and girls in Zimbabwe. Its central role is to provide a focal point for activism on women and girl's rights. WCoZ brings females from diverse backgrounds to collectively advocate for the attainment and enjoyment of their rights. The organisational members of the Coalition work in diverse fields including health, legal aid, access to education, gender based violence, torture, skills training, poverty reduction, research, property rights and governance issues. The Coalition has chapters in Bulawayo, Masvingo, Beitbridge, Kariba, Gweru, Gwanda, Bindura, Marondera and Mutare.

- Zimbabwe Women Lawyers Association (ZWLA), an association of women lawyers that was established in 1992, working to develop, defend and pursue women's human rights at local, regional and international level.

- Women of Zimbabwe Arise (WOZA), a civic movement in Zimbabwe which was formed in 2003 by Jenni Williams to provide women, from all walks of life, with a united voice to speak out on issues affecting their day-to-day lives; empower female leadership that will lead community involvement in pressing for solutions to the current political and economic crisis; encourage women to stand up for their rights and freedoms; and lobby and advocate on those issues affecting women and their families. WOZA is supported by Amnesty International. WOZA, the acronym of Women of Zimbabwe Arise, is a Ndebele word meaning 'Come forward'.

\section{Statement of the Problem}

Since the late 1990s, the relationship between the government of Zimbabwe and civil society organisations has been deteriorating. This has resulted in continuous friction in their operations. This study, thus, seeks to highlight some of the experiences and major challenges being faced by civil society groups, especially women civil society groups, in their struggle for social justice, using WOZA as case study.

\section{Research Methods and participants}

This study is a case study employing the qualitative research methodology. Qualitative research requires use of 
research instruments such as questionnaires, interviews, focus group discussions and observations. The researchers thus administered 25 open ended questionnaires in gathering data for this study.

The Women of Zimbabwe Arise Movement has a countrywide membership of over 55,000 women and men. The study sample consisted of 30 members of Women of Zimbabwe Arise in the city of Bulawayo. The researchers used a purposive convenient sampling technique to select participants.

Figure 1 shows age distribution of respondents. The study made use of participants from ages 20 to over 50 years. It is, however, important to acknowledge that the ages of membership in WOZA range from 16 years to over 60 years. Exclusion of the minors was meant to reduce complications in the data collection process whereby the researcher would also have to engage in the minors' families for consent. The majority of participants were between the ages of 30 and 39 followed by the 20-29 range possibly because they are the most productive age group, involving breadwinners who are thus directly exposed to the impacts of poor governance and human rights abuses.

Most of the women aged 40 years and above had been with the organization longest. This group had also been directly affected by the 1980 s Gukurahundi atrocities ${ }^{1}$ and the 2005 Operation Murambatsvina $^{2}$.

Figure 1: Age Distribution of Respondents

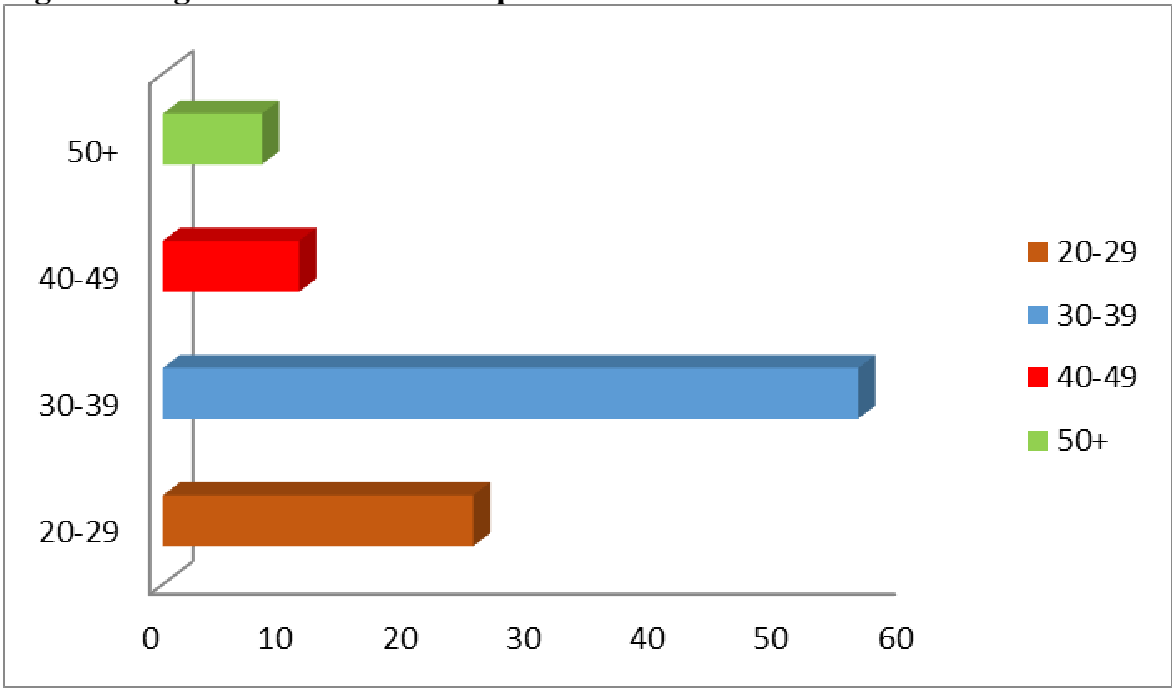

\section{Findings}

The majority of the respondents have participated in at least one peaceful campaign. The few who did not participate actively mentioned that this was so because of either the technical nature of their jobs, or because of their physical capacity as some are physically challenged to engage in street marches. Most of those who did not participate in street marches have participated in printing and posting petitions in some cases.

The following are some of the campaigns respondents took part in:

- $\quad$ the campaign for clean and plentiful drinking water in Bulawayo -Woza Moya Campaign 2012;

- demand for devolution of power to local leaders-Hoot/ Vuvuzela 4 Devolution;

- $\quad$ affordable and available electricity from ZETDC 2011;

- $\quad$ free and fair elections March 2008;

- $\quad$ inclusion of the public in SADC mediation 2007; and

- launch of People's Charter 2006;

This study found out that some of the pertinent issues being faced by WOZA are not clearly visible to a distant outsider. What is often noted is just a tip of the ice-burg. The iceberg theory observes that in several cases only a few details about a given situation are visible or known, whereas the bulk or real information is either unavailable or unknown. The Iceberg theory derives its name from the physical structure of an iceberg in the sea, which exhibits only its peak while its greater part is concealed beneath the sea.

Challenges faced by WOZA can be categorised into individual members and organisational challenges. Most common individual members challenges cited by respondents were human rights abuses by uniformed forces, particularly the Zimbabwe Republic Police (ZRP). Respondents said they were regularly arrested and detained for no apparent reason. During their peaceful demonstrations and campaigns they were beaten with

\footnotetext{
${ }^{1}$ In the 1980 s, in reaction to dissident insurgency following the ZANU PF landslide win of the1980 independence elections, the ZANU PF government sent the army to kill people in the Midlands and Matabeleland regions where the dissidents were operating from. Thousands of people (dissidents and civilians) were killed. This operation was given the name 'Gukurahundi'

${ }^{2}$ In 2005 the government destroyed all illegal residential structures and houses in urban and peri-urban areas leaving thousands of people homeless. This operation was dubbed 'Operation Murambatsvina'
} 
button sticks by armed police. As a result some of them were either maimed or sustained severe injuries. Some of them claimed that they were raped; exposed to inhuman torture like forcing a bottle into their sexual organ; insulted and called names like whores / prostitutes / beaches; and so on.

At organisational level WOZA faced challenges like lack of reliable and sustainable source of funding; violence from government sponsored groups (ZRP, youth, women); hatred by government authorities who saw the civic organisation as a front for Western imperialists; regionalism and tribalism (they felt that Bulawayo and Matabeleland were being marginalised simply because the region was largely Ndebele).

The macro-environment was said to be hostile, especially the regulatory and legal environment. Some of the hostile legislative instruments mentioned were the Public Order and Security Act (POSA) and Access to Information and Protection of Privacy Act (AIPPA) which limited freedom of expression and association among other things.

\section{Recommendations}

Guided by the above findings, the study makes the following recommendations:

- $\quad$ establishment of a national policy framework that encourages tolerance and acceptance of diversity, especially on political and other topical issues;

- the government is encouraged to respect citizens' views on matters that affect their everyday lives, especially women views on gender issues;

- the government is encouraged to be accountable and answerable to its actions, and even acknowledge some of its mistakes in public so that it does not over-react to complains by civil society organisations;

- cooperation between men and women in confronting their everyday social and political problems (WOZA have just coopted men into its membership and activities); and

- a partnership model by various stakeholders to solve the socio-economic problems bedeviling the country.

\section{References}

Helliker, D. K. (2012).Debunking Civil Society in Zimbabwe and 'Most of the World'. Seminar Paper for Critical Studies Seminar Series at Rhodes University, October $5^{\text {th }} 2012$.

Makumbe, J. (1998). Democracy and Development: Constraints on Decentralization. Sapes Trust, Harare.

Molutsi, P. (1999). The interaction between state and civil society in Southern Africa: Prospects for peace and security. Colorado: Boulder.

Monga, C. (1996). The anthropology of anger: Civil society and democracy in Africa. Colorado Boulder.

Moyo, J. (1993). Elections in Zimbabwe: hegemony and its incipient decline. African Journal of Political Science (1):103-121.

Sachikonye, L. (2007). Constitutionalism, the electoral system and challenges for governance and stability in Zimbabwe. African Journal of Conflict resolution. (2):12-26.

World Health Organisation. (2014). Trade, foreign policy, diplomacy and health: Civil society. http://www.who.int/trade/glossary/story006/en/. Accessed on 12 October 2014. 